This is the peer reviewed version of the following article: Leahy, S. , McKee, K. and Crawford, J. (2018), Generating Confusion, Concern, and Precarity through the Right to Rent Scheme in Scotland. Antipode, 50: 604-620, which has been published in final form at https://doi.org/10.1111/anti.12369. This article may be used for non-commercial purposes in accordance With Wiley Terms and Conditions for self-archiving.

\title{
Generating Confusion, Concern, and Precarity through the Right to Rent scheme in
}

\section{Scotland}

\section{Abstract}

The Immigration Act 2016 has heralded an era of amplified Government intervention into day-to-day life, placing increased responsibility for border protection on UK citizens. Using interviews with representatives from the field of housing in Scotland, this paper examines one specific aspect of the Immigration Act 2016, the right to rent scheme. We investigate how the right to rent creates a precarious environment for all those who may appear to be non-UK citizens. We argue that it may endorse senses of fantasy citizenship to inculcate people into acting on behalf of the state and is a driver for further division in society. Scotland provides a particularly interesting case study, as housing is a devolved power, but immigration is not. This creates an additional layer of tension in our interview data, as housing organisations are faced with a set of conditions imposed from Westminster, infringing on a field that Scotland has selfdetermined for some time. Our interviews illustrate the level of confusion around the scheme, the fact that it is increasing criminalisation in the housing sector, and stresses that the scheme is offloading state responsibility for border protection.

\section{Introduction}

The UK's Conservative party has been determined to increase restrictions around migration with the goal of cutting migrant numbers since they regained power in 2010. However, after an initial fall in immigration figures after the financial crash in 2010, the UK has been experiencing a rise in immigration since 2013. As a central tenant of the Conservative policy programme Prime Minister, Theresa May, in her previous position as Home Secretary, propelled the Immigration Act 2014 into law to ensure that the UK would "create a really hostile environment for illegal migrants" (Travis 2013). The Immigration Act 2014 was seen as a focal piece of legislation for the 
[Type here]

Conservative Party's political agenda with respect to reducing in-migration. It did so by inculcating the British public to enact the border on a routinized basis. This was a far-reaching extension of the Immigration Act 1988 that forced airlines and ferry companies to check immigration documentation of travellers on their services, and the Asylum and Immigration Act 1996, which compelled employers to check the documentation of their staff. Theresa May, when speaking on BBC radio's Today Programme, justified the need for the law by arguing from the principles of fairness and evenhandedness, contending that "most people will say it can't be fair for people who have no right to be here in the UK to continue to exist as everybody else does with bank accounts, with driving licenses and with access to rented accommodation. We are going to be changing that because we don't think that is fair" (Travis 2013). Since the suite of laws enacted in 2014 the UK Government have instituted the extension of this Act, with the Immigration Act 2016 coming into law in May 2016.

The Immigration Acts of 2014 and 2016 are aimed at those illegally working and residing in the UK, targeting undocumented workers and their employers, those driving while unlawfully in the UK, those with bank accounts, and those who are renting property. It furthermore provides extended powers of rapid deportation to State officers and introduces an immigrant skills charge for employers. The right to rent scheme, which began with a pilot in five local authorities in the West Midlands in December 2014, was launched in England in 2014 and extended to Scotland, Wales and Northern Ireland in 2016. It seeks to ensure that all prospective and current tenants have a legal right to reside in the UK and consequently rent property, and places the onus on the property owner to guarantee that their tenants can prove their legal right to be in the UK. The Act dictates that those who fail to adequately carry this out could suffer a five-year prison sentence, and/or a significant financial penalty (Crawford, Leahy et al. 2016). Renters, who do not have sufficient leave to remain in the UK or indeed proof of same, can now be evicted without need for a court order or sheriff involvement (Simeonova, Leahy et al. 2016). Since December 2014, two assessments of the right to rent have been conducted - one by the Home Office, and one by the Joint Council for the Welfare of Immigrants (JCWI) - both underlining discrimination against black and minority ethnic (BME) prospective tenants. A recent 
[Type here]

RLA (Walmsley 2017) survey of 810 landlords revealed "landlords are struggling to get to grips with the rules - with $63 \%$... afraid of making a mistake when checking documents". In reply to Parliamentary Questions submitted by Baroness Lister of Burtersett (after representations from the RLA), Baroness Williams of Trafford (2016) responded that "From 1 November 2015 to 31 October 201675 initial civil penalties were issued to individual landlords of tenants who do not have the right to rent in the UK... between the start of the scheme and 30 September 2016, 654 individuals were either named on a Civil Penalty Referral Notice served on a landlord, or encountered on an enforcement visit during which such a Notice was served, or encountered as a result of information provided through the Landlords Checking Service, or encountered as a result of other intelligence provided about property let to illegal migrants. Of these individuals, 31 were removed from the UK".

This paper examines the right to rent scheme, to better comprehend how the procedure is being understood and enacted by the people at the forefront of the scheme, the professionals who will need to ensure their compliance with the scheme on a routinized daily basis. This paper assesses this procedure from within the Scottish context. Scotland is an especially interesting case as housing is a devolved competency of the Scottish Parliament (McKee, Muir et al. 2017), however immigration is not. In the case of the right to rent scheme immigration law now is potentially trumping Scotland's control over its own housing legislation, opening up some interesting governance questions. This leaves a situation within Scotland whereby private landlords and housing associations are now deemed responsible and indeed accountable if they do not adequately check tenants' immigration documentation, citizenship status, and right to remain position within this country.

This paper asserts that this scheme will lead to further division in society along ethnic lines, has the potential to increase illegal activity in the housing sector, and additionally illustrates the precarious position the State places migrants and ethnic minority groups in. It does so under the banner of fairness for its own citizens, an issue we intend to question and challenge. We have found Butler's work on precarity and livable lives, and Anderson's (2016) concept of 'fantasy citizenship', especially 
[Type here]

illuminating in this context. This work and these concepts help us to elucidate how the right to rent scheme increases marginality in social relations, places an onus on citizens to check immigration compliance, completely disrupts the well-founded tenets of Scottish housing law, and extends the bordering practices in our society. We examine these concepts and others in more detail in the following section, these aid our understanding of the machinations of the Act. We then progress to inspect empirical interview data to unpack the central themes of our study.

\section{Creating Borders, Fantasy Citizens and Precarious Lives}

Balibar (2002) has noted that state institutions actualize and enact borders, both at the territorial limits of the state and within its boundaries in a dispersed and vacillating fashion. These bordering practices serve to catalogue and sort people into specific social categories and extend surveillance throughout society, enlisting citizens in border protection practices. In accordance with this, individuals are now seen to embody the border, carrying it with them, as bodies "become sites of encoded boundaries" (Amoore 2006, 347-8). Discursive and material bordering processes heighten suspicion and this regrettably means that individuals are now seen as bodies to mistrust, bodies that are in need of surveillance, control, and extraction from the state. The right to rent system actualizes these sentiments through the tenant immigration checking system. Crawford, Leahy \& McKee $(2016,120)$ have outlined this previously, claiming that 'it is this embodiment of the border that the Immigration Act relies on, drawing on landlords' notions of who is part of the territory and who is not. Leading them to make determinations by initially relying on who embodies the border for them'.

Guentner et al. (2016) utilise Balibar's work, amongst others' from the field of border studies, to discuss the production of hierarchical citizenship and social ordering within the UK. They examined the UK welfare system as a site of bordering, focusing on what they called "welfare chauvinism". They provide a historical understanding of the UK welfare system, explaining the ways in which welfare bigotry has become ingrained within British society, this, of course, stems far beyond the issue of housing and 
[Type here]

migrant rights. However, they have selected housing as one of the most prevalent areas where welfare chauvinism and bordering are evident within the UK, drawing on the right to rent system as an example of how prejudice has been extended to migrant groups. They demonstrate how discourses centred on a 'narrative of undeservingness' have been extended to migrant groups, beyond notions of deserving and undeserving poor, to allow biased and intolerant bordering practices to take place (Guentner, Lukes et al. 2016, 403). The narratives of deserving and undeservingness are longstanding facets of public discourse, which create 'myths of worthiness', as argued by Tyler (2013). She discusses the destructive nature of these discursive myths when talking about how New Labour pitted ' 'honest hard-working families' against the parasitical, pathological underclass' $(2013,170)$. Guentner et al's paper explains that there are an array of bordering practices at work in contemporary UK political and welfare systems, which are made all the more powerful by their ubiquitous and hidden nature, arguing that these are borders that are 'less visible than those at territorial frontiers, yet highly effective' $(2016,405)$. For these to work discourses must be actualized in the political and policy spheres to propagate these boundaries and allow them to become 'natural' facets of our daily interactions.

Correspondingly, Bridget Anderson maintains that immigration control and its enforcement has now 'become part of everyday life in Britain' $(2015,185)$. In her discussion of citizenship she states that people are constantly required to prove their legal status and citizenship within the British context, choosing the right to rent legislation as one example of this trend. Anderson argues that 'highly visible enforcement of the kind that we are increasingly witnessing does not only cause fear in migrant communities, it serves to tell citizens that citizenship has a value' (2015a, 186). This inconvenient and power laden relationship established around immigration checks, already inaugurates non-UK citizens as problematic, creating greater liability and paperwork for the citizen, and by extension putting the non-UK citizen in a more perilous position. Anderson argues that this serves to attract attention away from the inequalities between citizens within the UK and creates a type of 'fantasy citizenship' of inclusion. She reports that this inadvertently impacts 'differentiated citizens', noting that these are people who are more likely to be discriminated against in 
[Type here]

society, such as Black and minority Ethnic group members who may be more likely to have their documentation checked because of how they are regarded. Anderson asserts that 'Fantasy citizenship makes migrants exceptions and discourages a politics and an analysis that finds commonalities between migrants and differentiated citizens, even as it makes this analysis more urgent' (2015a, 187). She (2015a, 185) quotes from Liberty's briefing document on the Immigration Bill 2014 to contend that the law is 'an unprecedented collective extension of immigration responsibility'.

Dhaliwal and Forkert (2015) develop on Anderson's notion of fantasy citizenship through their discussion of the precepts of the laws enshrined within the Immigration Act. They argue that the rights to work and rent are pseudo rights, that "have been invented as if these actually meant something for national citizens (rather than being differentiated and contingent), in order to strengthen distinctions between those who hold national citizenship and those who do not' (Dhaliwal and Forkert 2015, 51). They also draw on Nicholas Rose's (1999) work on the neoliberal subject and Imogen Tyler's (2013) research on abjection to discuss how the Immigration Act works to further consolidate difference between citizens and non-UK citizens. Rose focused on the senses of individualism inherent in the processes of neoliberalism, whereby responsibility is expunged from the structures of a state and their workings and is instead placed on the individual. Meanwhile Tyler examines, through a variety of examples, how the state apparatus manages to create certain groups and individuals as 'dirty', 'defiled' and 'repulsive' to justify stigmatization and exclusion. All these ideas of fantasy citizenship, pseudo rights, the individualism inherent in the neoliberal world, and the strategies of state defilement of certain groups are key to understanding how a system like the right to rent works in practice.

Judith Butler's $(2004,2010)$ work on precarity and livability is very important and revealing when we think about the right to rent scheme and disposable bodies within the UK. Butler (2010) states that precarity is politically induced. It is engineered and mobilised through practice and discourse. In this respect we need to think about the role of institutions, both state and non-state, and the role of media in the dissemination of difference and the constitution of deviance as a way to perform 
[Type here]

sovereignty. Her discussions of precarious lives questions which lives are viable and which lives are not, and how they are made so. This is seen as being both a social and a political process, and as a series of activities where all life 'can be expunged at will or by accident; their persistence is in no sense guaranteed' (Butler 2010, 25). The capability of life is based on a system of dependency whereby 'one's life is always in some sense in the hands of another' (Butler 2010, 14). The notion of precarity highlights how vulnerable people's lives are to the decision-making of others, in this case to the executive decision of the landlord or their agent. This ties well to the notion of fantasy citizenship, further illustrating the power held within the political system, the institutions of the state, and within the hands of agents from the private rented sector to make decisions on the viability of renters' claims to belong. This unequal and power laden relationship brings further acrimony to society. It exposes all to the possibility of eviction, of not being able to find a place to live and obtain shelter, which is necessary for true existence and the maintenance of physical life. Butler's work on gender proves very pertinent in this context when she says that 'when we ask what makes a life liveable, we are asking about certain normative conditions that must be fulfilled for life to become life' $(2004,39)$. The need for safe shelter is surely one of these. This paper links and extends the work of Butler and Anderson to understand how the State's active role in the propagation of precarity utilizes notions of fantasy citizenship and markers of deservingness to interpellate all of us in their border protection strategies, extending division and discrimination in society as a result. The right to rent scheme is a contemporary and operational example of this.

\section{Methods}

Our paper draws on empirical data from an exploratory qualitative project in Scotland, which was designed as a seed corn project to a larger, future UK-wide project on the right to rent. The study adopted a purposive approach to sampling, to ensure a range of respondents were given the opportunity to be interviewed on this topic. We systematically reviewed 15 consultation responses ${ }^{1}$ and briefing papers from key

\footnotetext{
1 The consultation responses were from a number of stakeholder organisations and included the comments of the Scottish Refugee Council, Govan Law Centre, Association of Local Authority Chief Housing Officers (ALACHO), Scottish Housing Best Value Network (SHBVN), Chartered Institute of
} 
[Type here]

stakeholder organisations related to the right to rent legislation, these comprised of housing and homelessness charities, refugee and asylum seeker organisations, and landlords and umbrella groups who act in their collective interest. This identified a range of groups to approach for interview. They were invited to participate given their expertise on the potential implications of the UK Immigration Act, specifically the right to rent provisions. Through the examination of the consultation responses to the Act we noted the unanimous opposition of all groups in the sector. It was deemed prudent to approach as wide a range of stakeholder organisations as possible in order to obtain the fullest array of perspectives on their objections to the prescriptions of the right to rent.

In total our final sample included eleven semi-structured interviews, conducted during May and June 2016, with key actors working in housing policy and practice in Scotland. This included four participants from social landlord organisations, one social landlord representative group, a local authority umbrella group, a director and a policy officer from two different homelessness charities, a housing worker from a refugee charity, a senior lawyer who acts for landlords in eviction cases, and an employee from a charity specialising in rural housing issues. It must be noted that social housing, although a significant part of the entire housing sector in Scotland is, relatively speaking, a small 'field'. This is important, as we believe that, even with what may seem to the observer as a small number of interviewees, this sample is highly representative of this sector. Interviews were also sought with the Scottish Government, private landlord organisations, and organisations concerned with BME housing and Migrants Rights. However, these latter groups declined to participate. The BME community in Scotland is small and their organisations are stretched through over work and under funding, a factor which might have impacted their involvement in such research. The written responses from organisations such as Positive Action in Housing, Migrant Voice and Migrant Rights Scotland all opposed the Right to Rent. With respect to the PRS who did not respond for interview, it is important to note that the main PRS umbrella group in England published their own research findings, stating

Housing ( $\mathrm{ClH}$ ), Shelter, the Scottish Federation of Housing Associations (SFHA), Royal College of GPs in Scotland, Migrant Voice, Migrant Rights Scotland, and five Housing Associations. 
[Type here]

that $82 \%$ of their members opposed the Act's Right to Rent prescriptions, even before the penalty was increased from a fine to a five year prison sentence (Walmsley 2014).

As is standard in semi-structured interviews all participants were asked a common set of questions. The aim here was to gain insights into their understanding of the Act, potential tensions and challenges in implementing it in the devolved Scottish context, and the implications of the legislation for both landlords and tenants. All interviews were analysed thematically. To protect confidentiality all quotations presented in the analysis section of this paper have been anonymised, with only the participants' general organizational role indicated. Given the limited scope and time-scale of this seed corn project we recognize there are limits to our sample, and this is something we would seek to address in future follow up work. Nonetheless, we argue that there are important and interesting themes evident from our data, which have broader relevance for researchers interested in both housing inequalities and immigration, and we see this project as a vital precursor to further, more in-depth study of this topic.

\section{Confusion, Consternation, \& the Constitution of Precarity}

This paper centres on a series of mutual themes and shared points of concern for all of the organisations interviewed for this seed corn project. These commonalities focused on ambiguity about the Act generally and more specifically within the Scottish context. They emphasised the respondents' unease that the Act was not tackling their concerns about illegal activities in housing, and their apprehension around how the field of housing is being utilized as an arena to enact and diffuse the border and impose further barriers between UK and non-UK citizens, especially at a community level. We will examine each of these in turn, focusing first on uncertainty and the peculiarities of the Scottish context.

All those interviewed roundly rejected the Act and its precepts. There was comprehensive uncertainty around the Immigration Act, not only with respect to how the right to rent legislation impacts the devolved power of the Scottish Government, 
[Type here]

regarding its different context and legislation, but also how the right to rent legislation will be policed and monitored, and how the landlord will be brought to book, as well as who was liable and therefore at the mercy of the punitive conditions of the right to rent legislation - the Housing Association, the letting agent, or the (private) property owner. One respondent summed up this sentiment by stating that

'I think the uncertainty is how the courts will interpret whatever Westminster does, whatever the UK government does around this and the Home Office. I think there is a lot of uncertainty about how on earth they are going to progress that. I don't think they are making much progress on it at the moment and I think they are unlikely to make much progress in the next six months to year, just because there is quite enough going on' (Representative Membership Organisation 2).

This quote underlines how this level of ambiguity will cause problems for those policing this law, the courts, and its utilisation and application within an area such as Scotland where housing law is very different. Such a level of uncertainty means that landlords, who now must take the position of immigration assessor, may take the path of least resistance to avoid interaction with the precepts of this confusing law, which has as yet no precedence in the court.

Devolved Scottish housing law has no provisions for the right to rent legislation. Given the implications for housing rights and tenure security, the right to rent scheme further illuminates tensions between the Scottish and UK governments. Housing policy is a devolved competency under the 1998 Scotland Act, and indeed Scotland had its own distinctive housing policies and laws even prior to this. These devolved powers will be enhanced further following the implementation of the 2016 Scotland Act, affording the Scottish Parliament legislative powers in new areas including tax and welfare (for further details of devolved powers see McKee, Muir et al. 2017).

At present there are important and notable differences in housing rights across the UK, with Scotland at the forefront of offering tenants' greater protection. Both housing association and local authority tenants benefit from secure tenancies, and unlike in England, there are no time-limited tenancies, and rents are not linked to 
[Type here]

income (McKee and Phillips 2012, McKee, Muir et al. 2017). For those renting privately the recent Private Housing (Tenancies) (Scotland) Act 2016 introduced streamlined model tenancies, ended the 'no fault' ground for possession, which allowed landlords to terminate a tenancy at the end of a contractual period, and limited rent increases to once per year, with local authorities also having scope to implement rent control in certain areas (Her Majesty's Stationary Office 2016, McKee, Muir et al. 2017). Progressive homelessness legislation in Scotland that removed 'priority need', also entitles all homeless households, including those under threat of eviction, to settled accommodation as a legal right (McKee and Phillips 2012). Moreover, the Housing (Scotland) Act 1987 protects all tenants against summary eviction, affording them a right to remain in the property until a decree has been enacted by Sheriff Officers (Crawford, Leahy et al. 2016). These distinctive and important housing rights are however all being undermined and threatened by the implications of the right to rent provisions of the 2016 UK Immigration Act. One interviewee stated

... Scottish residential tenancy law is very complicated... So to think that UK Government would be able to legislate on that, that's really problematic... So I think there are huge questions to be answered on that and I think that process of figuring out which Government has the power to do what needs to be, that needs to be an open discussion. We need to understand the, I guess, where it's a grey area as to where devolved matters ended and reserved matters begin' (Homeless and housing charity 1 ).

Another questions the very right of the UK Government to supersede Scottish law and devolved competency

'...by using immigration, by calling it immigration law, the UK Government believes that this immigration law, it's within their jurisdiction... We have got some real concerns about that. We need to look into it further. We need to be able to say with a degree of certainty about what that means and whether it could be challenged as a bit of law.' (Representative Membership Organisation $3)$.

The new Immigration Act means that landlords will be able to evict tenants with no legal 'right to rent' after only 28 days' notice, and without the normal statutory 
[Type here]

safeguards of obtaining a decree from the Sheriff Court. Furthermore, landlords will be able to enter into time-limited tenancies (linked to the tenants' eligibility to remain in the UK), putting it into direct tension with the new Scottish private sector tenancy, which allow tenants to remain in the property indefinitely, unless they wish to leave, or the landlord has prescribed grounds for eviction. Interviewees spoke about this set of tensions and the issue of eviction specifically and repeatedly. One Interviewee argued that

'You see the 40 day notice, the fact that you have to go to a Sheriff court to get a decree otherwise it is an illegal eviction and you have to get Sheriff officers to serve that. These three things, which underpin the rights of tenants in Scotland, have existed since the Housing Act of $1550 \ldots$ All of that just goes away, all of that is nearly 500 years of tenancy rights imbedded within these acts in Scotland are worthless because what this is saying is you do not need to go to court you just evict them if you do not think that they have leave to remain. Evict' (Housing Association 2).

The issue of confusion and uncertainty discussed above was again at the forefront of this concern around devolved power and eviction. Another interviewee stated that

'Scotland has had a different approach to housing, and particular under homelessness... the duty to give temporary accommodation to any one presenting as homeless in Scotland is very different and that duty to provide temporary accommodation has a financial implication, which is not really reflected properly in the benefits system' (Homeless and housing charity 2 ).

The same respondent went on to proclaim that

'I am still confused to how this is going to work in practice, because housing policy and legislation is a matter for the Scottish Government. We have just passed a Private Tenancies Act which changes the tenancy rights in the Private Rented Sector and it makes it absolute clear that there are only specific grounds on which somebody can be evicted, and it doesn't include somebody not having "right to rent" in the UK legislation. So I don't know how you could have a legal eviction of somebody who doesn't have the right to rent under Scottish Housing Law' (Homeless and housing charity 2). 
[Type here]

However, as immigration remains a reserved power of the UK Government the Scottish Government has no legislative power in this area, and can do little in legislative terms to resist the measures. Indeed, for the right to rent provisions to be implemented in Scotland, the Scottish Parliament would be required to pass secondary legislation to amend the tenancy arrangements that currently exist in Scotland for both social and private renters. As another interviewee discussed

'If they go ahead with what is proposed in England, where a landlord can simply summarily evict, that completely undermines the messages from the Private (Tenancies) (Scotland) Act. The whole point about that was to get a very clear message to private landlords that every eviction has to be subject to a process...I think it reinforces all of that bad practice about illegal evictions, which we have been trying to eliminate' (Homeless and housing charity 2).

This not only raises numerous practical implementation questions, and would undoubtedly take time to do, but also poses more fundamental questions about the nature of the constitutional settlement and the relationship between Holyrood and Westminster. In particular, whether the UK Government has the right to legislate in this area, and exactly where the boundary between devolved housing law and reserved immigration powers should be drawn. In this regard, it is interesting that the legal representative interviewed asserted that

' just think, if the Home Office try and push this in Scotland, there's going to be significant political resistance to it. I think this legislation is very much seen as a Tory/Conservative right wing knee jerk reaction to a problem that doesn't actually exist, and in Scotland we certainly would go by majority government and we certainly have a massive majority left of centre, in Parliament. If you have a vote in Scotland you'd have 97/31 against the Act, effectively, I can't imagine the Lib Dems voting in favour of this' (Housing Lawyer).

The relationship between the Scottish Government and its citizens is often imagined as quite different than that of the UK Government. The Scottish Parliament prides itself on its social democratic policy ethos, and offers within the limits of its devolved powers, a stronger safety net for its citizen. Since its inception in 1999 the Scottish Parliament has passed a raft of legislative measures that have strengthened the rights 
[Type here]

of homeless people and tenants alike, with social housing being the focus of the first decade of the $21^{\text {st }}$ century and private rented tenants becoming the beneficiaries of legislation introduced in the second decade. The Housing (Scotland) Acts of 2001 and 2010 as well the Homelessness Etc., (Scotland) Act 2003, gives homeless persons and tenants a wide-ranging package of rights. That said, until recently, provisions in the private rented sector (PRS) were still lagging behind much of Europe with regard to regulation and standards. The Private Housing (Tenancies) (Scotland) Act 2016 is a clear attempt to address this shortcoming, providing a package of rights in both the social housing sector and the PRS which far exceeds that in England and Wales.

Beyond the Scottish context many were apprehensive about the effectiveness of the Act to make any real difference to the 'migrant crisis' being articulated by the UK Government. One interviewee asserted that

'I don't think it's going to reveal the whole lot because actually, the murkier side of illegal immigration are people who are trafficking people where no money changes hands, where the right to rent doesn't come into play whatsoever, and actually as I have said on some other things, I think we give more power to these slave masters and gang masters through this' (Homeless and housing charity 2 )

This formulates a very relevant and pressing concern about illegal activity; an area interviewees felt needed greater attention. It also focuses concern on a number of central questions - who are the main targets of this Act, what does this Act hope to achieve, is this Act focused on the wrong aspects of migration, shouldn't it pay more consideration to the illegality present in the criminal practices involved in trafficking and the housing of those trafficked. Those interviewed felt that the notable concern for migrants in housing was the prevalent and hidden nature of landlords involved in illegal activity, rather than legal landlords openly renting to those the state deemed to be 'illegal'. One interviewee argued that

'The worry about anything like this is that the real hard end criminal landlords will still find a way of evading this, it's what usually happens is that you still, you know to find a way of getting to the real, real sharp end really would depend on how well the PRS more generally in a given area is policed ... when 
[Type here]

the minority ... that will crowd 12 people into a room or whatever, you know just still do not get routed out' (Representative Membership Organisation 1). It was felt that these landlords involved in illegal activity would have the monopoly to rent to those without paperwork, fostering the propagation of illegal or unsafe and overcrowded properties, which could be rented by those who would benefit unduly from the uncertain position of minority groups. One interviewee summed this up by saying that the practice of checking documentation will create an air of fear and trepidation, word will spread, and tenants will think

'Don't go near them because they will report you to the Home Office. That's awful... It is just going to drive people underground to be exploited. It is just absolutely not what we should be doing'(Housing Association 1).

Many respondents feared that this would lead to a rise in illegality in the housing sector and push the issue further underground. An interviewee contended that

'if people can't get it by legitimate means, then people are likely to get it by illegitimate means. There are landlords throughout the UK who flout legislation on overcrowding, on repairs. Those landlords will continue to operate and we can see how legislation like this would stop landlords like that operating who may well already be operating illegally anyway by vastly overcrowding their properties, by arbitrarily bringing people in, evicting people, doing all the things that landlords should do' (Representative Membership Organisation 3).

Through the right to rent legislation the UK is making it more difficult for prospective tenants to attain housing easily and legally, and are driving a further wedge between those who let their property and their prospective tenant. This links well to Butler and Spivak's (2007) work on the nation state and sovereignty, when they argue that the State has the potential to bind and unbind people from its very being. This legislation is binding the landlord to the State, as it compels the landlord to enact status checking on the State's behalf. On the flip side of this it provides evidence of a further disentangling of the State and its citizens from those who are deemed to be 'illegal' in the country. This unbinding of relations between people creates an atmosphere of 
[Type here]

mistrust, is a further catalyst to maintain division in society, and serves to draw attention away from State practices and place blame and an air of suspicion on all those who 'appear' to be outsiders. It serves to further instil a hierarchy between citizens and non-UK citizens and creates another layer in the system of dependency that fuels precarity. Such precarity is further evident in the prospect of tenants having to deal with illegal landlords involved in criminal activity.

As mentioned above those interviewed were concerned that landlords, especially those in the private rented sector, would take the easy option as it were and refrain from taking minority ethnic group members as tenants, rather than have to deal with the legislation. This is especially true when the majority of private landlords own between one and three properties (Soaita, Searle et al. 2017). The stress and punitive risk involved may deter landlords, especially those with a small portfolio, from exposing themselves to the possibility of retribution from the State. An interviewee contended that

'the private landlord reps were quite upfront about it. They said look, if you are a private landlords with one property and you have got the option of someone who looks or sounds foreign, who might be a risk, or someone who looks and sounds and has a name which is obviously indigenous you are going to take the no risk option. Why put yourself through it?.. It is just about the path of least resistance, the path of least hassle' (Homeless and housing charity 2).

This attitude means that those whose area of origin is in question are placed in an even more vulnerable position. This has been noted by Anderson, when she contends that 'Citizens have rights that migrants do not, which is why migrants must be checked up on' $(2015,186)$. The perceived risks involved bring uncertainty; a chance of liability and, at minimum, inconveniences the landlord. The proposed processes exasperated one interviewee, declaring that

“... people are just like this is more hassle than it's worth and you will probably use an excuse. Oh well sorry, I have got two people interested and they were here first' (Housing Association 1). 
[Type here]

Another interviewee, when speaking about the private rented sector and the initial reports on the right to rent pilot scheme in England, stated that they had seen that private landlords were

'...not entertaining applications from people who you thought you were going to have to go through all those checks with, it is quite clear that was there, and I saw a disconnect between what the pilot found and how it was reported because there was clear discrimination' (Representative Membership Organisation 1).

By making landlords active border agents these Immigration Act requirements further strengthen the marginalization of ethnic and migrant groups, by formulating relations between migrants and citizens in a more regimented, business-like and increasingly bothersome fashion it proves to be stressful for both parties, accentuating a hierarchy and dependency between citizen and noncitizen. Butler argues that 'everyone is precarious' as 'we depend upon one another' $(2012,148)$. She (2012) highlights the human need for shelter when elucidating what makes lives precarious, previously explaining that precarity pervades our lives and is deeply relational as it is 'a dependency on people we know, or barely know, or know not at all' $(2010,14)$. This dependency is ever evident within the right to rent system. The renter is reliant on the landlord and the landlord's view of their very selfhood, harking back to Amoore's (2006) work on embodiment of the border.

Guentner et al's (2016) arguments with respect to highly effective bordering and chauvinistic decision making are already predicted by those within the field of private housing in Scotland. There was an extensive concern throughout all of the interviews that the right to rent legislation would lead to greater discrimination within the housing sector more broadly, but most especially at a community level. One interviewee exemplified this opinion when they declared that

'... actually if you're starting to ... divide people and say, well you can come in, and you can't, ... It changes the relationship between you and the tenant's and the community' (Charity 2 ). 
[Type here]

This additionally taps into Anderson's arguments on fantasy citizenship, propagating hierarchical decision-making based on ethnicity and country of origin. Anderson $(2015,196)$ contends that 'fantasy citizenship reifies an axis of difference, implicates citizens in the making of that difference, promises to protect citizens from that difference, as if that difference were the only one that matters, as if this is enough and everyone should be grateful for it'. Underscoring fantasy citizenship is the notion of competition, a series of struggles between those who are deemed to be citizens and those who are not. Such legislation highlights the precarious tiered relationship between the renter and would-be tenant, as Butler stresses 'our precarity is to a large extent dependent upon the organization of economic and social relationships, the presence or absence of sustaining infrastructures and social and political institutions' $(2012,148)$.

Isabell Lorey in discussion with Jasbir Puar states that 'I use the term "precarity" (Prekarität) as a category of order that denotes social positionings of insecurity and hierarchization, which accompanies processes of Othering' (Puar 2012, 165). The right to rent legislation extends the gap between those who are easily identifiable as British and those who are not. It places the onus on those who do not immediately appear British to prove their citizenship. It allows certain groups to become seen as disposable, it heightens discrimination and disparity within society as it plays directly on people's immediate recognition of what they believe to be phenotypically British.

\section{Striving for Equality in an Overburdened Sector}

All those interviewed for this study stressed that there needed to be equity and fairmindedness in the inspection of all tenants and their identity documentation no matter their citizenship status (UK or non-UK). For this equality of process to be applied to all, all those who apply to rent should have their immigration position recorded and rights to remain status checked. This poses a number of problems centred on documentation provision, knowledge and training, and fairness of procedure. It was noted on numerous occasions that prospective tenants may not 
[Type here]

possess the relevant documentation such as a driving license or passport as these cost money and renters may have previously had no need for them.

An interviewee makes the point that

'...we have some people who are white Scottish who would struggle to provide the documentation' (Housing Association 1).

This further highlights the fact that precarity is 'constantly shifting' (Anderson 2015b). It allows for the production of certain bodies as precarious now, while others will be more precarious at other times. Precarity is therefore relational and can be turned on like a switch; this switch can consequently be amped up or turned down relative to the assumed levels of vulnerability and threat.

This law is centred on the right to hold a legal tenancy within the UK and was developed from Government efforts to create a hostile environment, but to what extent is it creating a hostile environment for the very people it is purporting to aid? Initial debate around the Immigration Act 2014 and the rental system focused on claims that the immigration checks in the rental sector would curtail homelessness of British citizens. However, the interviewees spoken to in this study fear the opposite because of the barriers that will be created for prospective tenants, their reduction of security of tenure and protection from eviction. One respondent pointed out that

'there will be a good tranche of half decent private landlords who will not turn somebody away at the door or the letting agencies so they will start doing the checks, but if that person just cannot come up with the right documents, ...that is where your decent private landlord might think I cannot take that risk and you have not got your passport, you have not got whatever, ...I mean it is almost, shall we say understandable discrimination because they have tried it down the route of the checks, a person cannot tick the box, what they are supposed to do as a private landlord' (Representative Membership Organisation 1).

Another stated

'That was one of the issues I raised and some of our responses was that there is an irony in this, which is that actually, for example, homeless people, a homeless person from another EU country is far more likely to have an ID card 
[Type here]

because you are legally obliged to have one in most countries of the EU than an indigenous UK homeless person. So it might actually be excluding indigenous UK homeless people from access to accommodation and favouring other EU migrants. Now that is not the intention of the legislation, but it is one of these perverse outcomes' (Homeless and housing charity 2).

As Anderson explained when outlining her understanding of fantasy citizenship: 'in practice, citizens' 'right to rent' only means something when contrasted with non-UK citizens not having it. The right to rent constrains non-UK citizens but it does not enable citizens' (Anderson 2015a, 187). Dhaliwal and Forkert's (2015) pseudo rights are consequently wholly apparent.

Moreover, training in equitable practice with respect to the review of immigration documentation is required. One respondent summed this up in relation to the right to rent scheme by saying that

'it will be a bit hit and miss whether or not they have the cultural sensitivity to ask the right questions in the right way or as opposed to simply saying well if it looks as if I am going to have to ask these questions, I am not going to engage with you. I am just not going to even consider letting to you' (Representative Membership Organisation 2).

Those interviewed stressed that adequate and appropriate training will need to be put in place for all those who deal with prospective tenants around the issue of right to remain paperwork, how to deal with this appropriately and sensitively, and how to be mindful when checking what could prove to be a variety of documentation. It was specified that

'it needs to be done properly, but that means investing in training and skills development, so folk have got the awareness and the sensitivity to ask those questions. So your published material needs to be drafted in the right way'(Umbrella Organisation 2).

Another asked

'How do private landlords, even if they desire to be a good private landlord, how do they get all that education and all that knowledge? Where does that come from?' (Housing Association 1). 
[Type here]

This also brings with it financial implications for training, process building and appropriate certification, to an already stretched sector. This not only affects housing associations, it further burdens the private rented sector, which is comprised of multiple small landlords, many of whom may be accidental landlords (e.g. inherited property), whereby letting may not be their main profession or source of income. Those using letting agents may be subject to additional service charges in terms of managing the tenancy process with respect to the right to rent system.

\section{'Why is it our responsibility? I don't think it is.'_(Housing Association 1)}

A number of those interviewed explicitly stated that landlords and housing associations should not be made extensions of the border mechanisms of the state, this will only lead to greater divisiveness within society and place greater risk on an already stretched system, and shirk responsibility onto those who are not qualified to make such judgments on immigration legality. As Rose (1999) argues, accountability is again being placed at the feet of the individual and away from the State. Balibar's (2002) vacillating border is constantly in evidence. It is snaking its way through society, poisoning relationships and placing culpability and obligation for its monitoring and patrol on all individuals who must enact it. This border policing within the housing sector brings with it extensive consequences of failure to patrol, but also the positive feedback of responsibility, which fosters Anderson's (2016) notion of 'fantasy citizenship' and inclusiveness in the functioning of the State. Creating hierarchies and imbuing the citizen with decision-making power over whose lives should be deemed liveable. One respondent clearly stated that

'I thought it was the rule or the remit rather of the Home Office and Border Control and its obviously, I feel maybe they are not doing their job enough and it is like passing the buck onto housing' (Rural Housing Organisation).

Another vehemently pointed out that

'...we become immigration officials and that is not why people work in housing. Absolutely not... I mean, my previous understanding that we would have to report things to the Home Office that made me uncomfortable in itself. But when it's a duty and it's enforced on you and there's legal penalties for not 
[Type here]

doing so, then finally you accept that ...we have to comply with it. But I definitely do not think it's our role to be implementing the Home Office' (Housing Association 1).

This legislation is forcing all landlords to act politically, and as Lorey claims, any such situation of political action is 'always structured through various forms of precarity' (Puar 2012, 172). Anderson (2015a \& 2015b) argues that this series of practices naturalises deportation and immigration inspection, and this heightened awareness of the legalities around immigration, reifies and strengthens the position of the citizen within the State in comparison to the non-UK citizen. An interviewee sums this up by arguing

'But if someone is asking them for their documents who has a degree of power over whether they get accommodation, whether they get evicted and all of those things, that level of confusion rises because, who are you? Are you a member? Are you a representative of the state? Are you from the home office? What this legislation does is it off loads the duties of the state to check and ensure that it knows what and where its citizens are broadly onto landlords who are ill-equipped to do it effectively' (Representative Membership Organisation 3).

This reminds us of Dhaliwal and Forkert's (2015) pseudo rights, whereby a scheme like the right to rent instils the sense that this is a right for those who are deemed to be part of UK society and it should be used and endorsed by UK citizens on non-UK citizens. This enhances UK citizens' sense of state responsibility and power and reifies a right that does not exist in any real sense. It also contradicts the spirit of the legislative measures introduced in Scotland since the inception of the Scottish Parliament in 1999, which were about extending rights to all groups and providing a comprehensive a package of statutory responsibilities which landlords had towards the homeless and to tenants of both social housing and the PRS.

\section{Concluding Thoughts}

Let us think again back to Theresa May's speech in 2014 about the need for fairness and even-handedness with respect to migrants in the UK. How have the immigration acts brought fair-mindedness, justice, and equality? Indeed one must question if they 
[Type here]

have brought any of these things. The 'hostile environment' has certainly been fostered, but it is a hostile environment to unsettle more than just those deemed by the State as 'illegal' migrants. Such an unsettling environment is being created by the State in more areas than housing. Currently there is evidence of the recording of nationality in the education system (McInerney 2016) and in maternity services (Dearden 2015), to name just two. This paper has clearly shown that the right to rent legislation aspect of the Act has heralded the opposite to fairness. It has proclaimed division, disunity, and distrust, it brings with it confusion and fear about what and who it relates to, how the right to rent system will be checked and policed, what it means for the Scottish context and its future housing legislation, and how it will be rolled out and instituted. It underlines the role of the State in the production of precarity, it illustrates how the State mobilises a fantasy citizenship to maintain division, and inculcate individuals to act as border agents for the State's monitoring and protection. It creates discord and furthers the polarisation of ethnic minority groups in UK society. It serves to propel vulnerability, to make lives less liveable, more perilous, and increasingly exposed to the potential of erasure. Shami Chakrabarti, the Director of Liberty, speaking directly about the right to rent legislation has stated that, 'as with stop and search and other sources of discrimination, the Immigration Act will do enormous harm to the equality and solidarity that binds people, communities and countries together' $(2014,124)$. The qualitative evidence presented here highlights the extent to which the Immigration Act has caused confusion, concern and precarity. If anything this evidence should persuade us to take Chakrabarti's warning seriously. 
[Type here]

\section{References}

Amoore, L. (2006). "Biometric borders: Governing mobilities in the war on terror." Political Geography 25: 336 - 351.

Anderson, B. (2015a). "'Heads I Win. Tails you Lose.' Migration and the Worker Citizen." Current Legal Problems 68(1): 179-196.

Anderson, B. (2015b). Immigration and the worker citizen. Citizenship and its Others B. Anderson and V. Hughes. UK, Palgrave Macmillan 41-57.

Anderson, B. (2016). "Against fantasy citizenship: the politics of migration and austerity " Renewal: a Journal of Labour Politics 24(1): 53 - 61.

Balibar, E. (2002). Politics and the Other Scene, Verso.

Butler, J. (2004). Precarious life : the powers of mourning and violence. London, Verso.

Butler, J. (2004). Undoing gender. USA, Psychology Press.

Butler, J. (2010). Frames of war : when is life grievable? London, Verso.

Butler, J. (2012). "Precarious life, vulnerability, and the ethics of cohabitation." The Lournal of Speculative Philosophy 26(2): 134-151.

Butler, J. P. and G. C. Spivak (2007). Who sings the nation-state? New York, Seagull Books.

Chakrabarti, S. (2014). On Liberty. UK Penguin.

Crawford, J., et al. (2016). "The Immigration Act and the 'Right to Rent': exploring governing tensions within and beyond the state. ." People Place and Policy Online. 10(2): $114-125$.

Dearden, L. (2015). Patients must show passport to use NHS or pay more than $£ 2,000$ in 'health tourism' crackdown. The Independent London

Dhaliwal, S. and K. Forkert (2015). "Deserving and undeserving migrants." Soundings 61: 49 - 61.

Guentner, S., et al. (2016). "Bordering practices in the UK welfare system." Critical Social Policy 36(3): 391 - 411.

Her Majesty's Stationary Office (2016). Private Housing (Tenancies) (Scotland) Act 2016._http://www.legislation.gov.uk/asp/2016/19/contents/enacted.

McInerney, L. (2016). Schools should not make parents show their children's passports. For anything. Schools Week 
[Type here]

McKee, K., et al. (2017). "“Housing Policy in the UK: the importance of spatial nuance"." Housing Studies 32(1): 60 - 72.

McKee, K. and D. Phillips (2012). Social Housing and Homelessness Policies: reconciling social justice and social mix. Social Justice and Social Policy in Scotland. . G. Mooney and G.Scott. Bristol, Policy Press. : 227-242.

Puar, J. e. (2012). "Precarity Talk: A Virtual Roundtable with Lauren Berlant, Judith Butler, Bojana Cvejić, Isabell Lorey, Jasbir Puar, and Ana Vujanović." TDR/The Drama Review 56(4): 163-177.

Rose, N. (1999). Powers of Freedom: Reframing political thought. Cambridge, Cambridge University Press.

Simeonova, M., et al. (2016). Immigration Act 2016 - More harm than good? St Andrews CHR Policy Briefing

Soaita, A. M., et al. (2017). "Becoming a landlord: strategies of property-based welfare in the private rental sector in Great Britain." Housing Studies 32(5): 613637.

Trafford, B. W. o. (2016). Undocumented Migrants: Private Rented Housing:Written question - HL3409. London, http://www.parliament.uk/business/publications/written-questions-answersstatements/written-question/Lords/2016-11-22/HL3409/: http://www.parliament.uk/business/publications/written-questions-answersstatements/written-question/Lords/2016-2011-2022/HL3409/.

Travis, A. (2013). Immigration bill: Theresa May defends plans to create 'hostile environment'. The Guardian. London.

Tyler, I. (2013). Revolting subjects : social abjection and resistance in neoliberal Britain, Zed Books.

Walmsley, S. (2014). "Immigration: pilot area decided." Retrieved 29/05/2017.

Walmsley, S. (2017). "Right to rent sees 31 deported." Retrieved 29/05/2017. 